\title{
Phytoremediation of arsenic-contaminated water: the role of antioxidant metabolism of Azolla caroliniana Willd. [Salviniales]
}

\author{
Gabriela Alves Leão', Juraci Alves de Oliveira² ${ }^{2}$ Rafaella Teles Arantes Felipe ${ }^{2}$ and Fernanda Santos Farnese ${ }^{3^{*}}$
}

Received: November 19, 2016

Accepted: February 22, 2017

\begin{abstract}
Phytoremediation has proven to be an efficient technology for removing arsenic (As) from water, but the plants used in this process need to be tolerant to the damage caused by As. The toxic effect of As on growth and functioning of the antioxidant system was studied in individual plants of Azolla caroliniana exposed to five concentrations of As ( $0.0,0.25$, 0.5, 1.0 and $1.5 \mathrm{mg} \mathrm{L}^{-1}$ ) for the course of five days. Growth, As absorption, enzymatic activity, total and non-protein thiols and anthocyanin content were assessed. Azolla caroliniana was able to take up large amounts of the pollutant, reaching As concentrations of $386.1 \mu \mathrm{g} \mathrm{g}^{-1}$ dry weight without saturating the absorption mechanism. The tolerance index and the growth of $A$. caroliniana decreased with the increased As uptake. Superoxide dismutase, peroxidases, catalases and glutathione reductase activities increased at lower doses of As and subsequently declined with higher concentrations, whereas ascorbate peroxidase activity was reduced in all treatments. Unlike the enzymatic defence system, anthocyanin and thiol content increased consistently in all treatments and showed a positive correlation with As concentration. Therefore, the increased synthesis of non-enzymatic antioxidants is most likely the main factor responsible for the high As tolerance of A. caroliniana.
\end{abstract}

Keywords: anthocyanin, antioxidant enzymes, aquatic plant, thiol compounds, water remediation

\section{Introduction}

Arsenic (As) is a toxic carcinogenic metalloid ubiquitous in the environment with both anthropogenic and geogenic origins. Potential sources of As contamination include mining activity and chemicals used extensively in agriculture as pesticides, insecticides, defoliants, wood preservatives and soil sterilants (Fayiga \& Saha 2016). Water polluted with As requires special attention because contaminated water used for drinking, food preparation and irrigation of food crops poses one of the greatest threats to public health (Karn 2015; Palácio et al. 2016; Sadee et al. 2016).

There are several methods to remove As from water, including physical, chemical and biological methods. Among them, the use of aquatic plants, or phytoremediation, is an efficient, viable and low-cost technology (Farnese et al. 2014). Plants used in phytoremediation should be able to remove the pollutant from the environment and be tolerant to damage caused by it (Podder \& Majumder 2016). One of the most damaging effects of As in plants is oxidative stress caused by an increase in the production of reactive oxygen species (ROS), which may alter the normal metabolism

\footnotetext{
${ }^{1}$ Instituto Federal Baiano, 45810-000, Porto Seguro, BA, Brazil

${ }^{2}$ Departamento de Biologia Geral, Universidade Federal de Viçosa, 36570-000, Viçosa, MG, Brazil

${ }^{3}$ Instituto Federal Goiano, Campus Rio Verde, 75906-820, Rio Verde, GO, Brazil

* Corresponding author: fernanda.farnese@ifgoiano.edu.br
} 
of plants and damage cell membranes, causing inhibition of photosynthesis and growth (Silveira et al. 2015) and eventual cell death (Sharma et al. 2012). However, plants have developed mechanisms to mitigate these effects using enzymatic and non-enzymatic antioxidants, such as superoxide dismutase (SOD), peroxidases (POXs) and catalases (Gusman et al. 2013), as well as anthocyanins (Srivastava et al. 2016) and non-protein thiols (Leão et al. 2014b).

Azolla caroliniana is an aquatic plant with high potential for phytoremediation programs due to its capacity to accumulate metals such as cadmium, chromium, nickel and zinc (Benniceli et al. 2004). Within the genus Azolla, A. caroliana has the highest capacity to accumulate toxic levels of As, however, little information is available about the mechanisms underlying the As tolerance of this plant (Zhang et al. 2008). Based on these facts, this paper aims to verify the role of the antioxidant system in the As tolerance of $A$. caroliniana exposed to five concentrations of the pollutant.

\section{Materials and methods}

\section{Plant exposure to arsenic}

Specimens of Azolla caroliniana L. collected in nonpolluted dams at the Federal University of Viçosa, Viçosa, Minas Gerais State, Brazil (2045'25.0”S 4252'25.5”W) were used in all experiments (average ambient temperature between 20.6 and $25.2^{\circ} \mathrm{C}$ and average annual precipitation of $1229 \mathrm{~mm}$ ). Plants were surface sterilized with $1 \%$ sodium hypochlorite for $1 \mathrm{~min}$ and extensively rinsed with running tap water and deionized water. Next, the plants were transferred to polyethylene pots with $10 \mathrm{~L}$ of Clark's nutrient solution (pH 6.5) (Clark 1975) and maintained in a growth room with controlled temperature and irradiance $\left(25 \pm 2{ }^{\circ} \mathrm{C}\right.$; $230 \mu \mathrm{mol} \mathrm{m}^{-2} \mathrm{~s}^{-1}$ ) under a photoperiod of 16 hours for a acclimatation period of 3 days. After the acclimatation period, plants (approximately $1 \mathrm{~g}$ fresh weight were transferred to $0.5 \mathrm{~L}$ polyethylene pots containing Clark's nutrient solution ( $\mathrm{pH}$ 6.5) in the absence or presence of As $(0.0,0.25,0.5,1.0$ and $1.5 \mathrm{mg} \mathrm{L}^{-1}$ ), supplied as $\mathrm{Na}_{2} \mathrm{HAsO}_{4} \cdot 7 \mathrm{H}_{2} \mathrm{O}$, for 5 days. At the end of the experiment, plants were washed with $0.1 \mathrm{M}$ $\mathrm{HCl}$ to desorb metals form the surface of the biomass and triple rinsed with deionized water. Samples were frozen in liquid nitrogen and stored at $-80^{\circ} \mathrm{C}$.

\section{Arsenic uptake and its effect on the growth and tolerance index of $\boldsymbol{A}$. caroliniana}

Plants were washed with deionized water and placed into a conventional oven at $80^{\circ} \mathrm{C}$ until constant dry weight was achieved. Plants were then digested (Marin et al. 1993), and the As concentration was analyzed using an hydride generation atomic absorption spectrophotometer
(Shimadzu $\left.{ }^{\circledR}, A A 6701 F\right)$. The relative growth rate (RGR) of the plants was calculated using the equation proposed by Hunt (1978):

$$
\mathrm{R}_{\mathrm{w}}=\left(\ln \mathrm{w}_{1}-\ln \mathrm{w}_{0}\right) \times 1000 /\left(\mathrm{t}_{1}-\mathrm{t}_{0}\right)
$$

where $R_{w}$ represents relative growth rate; $\ln w_{1}$ e $\ln w_{0}$ represents neperian logarithm of the mass at the end and beginning of the experiment, respectively; and $t_{1}-t_{0}$ represents duration of the experiment (days).

The As tolerance was estimated by calculating the tolerance index (TI) (\%), as proposed by Wilkins (1978):

$$
\mathrm{TI}(\%)=\left(\mathrm{Rw}^{*} / \mathrm{Rw}\right) \times 100
$$

where $\mathrm{Rw}^{*}$ is the relative growth rate of plants in solution with As, and Rw is the relative growth rate of plants in solution without arsenic.

\section{Effects of arsenic on enzymatic activity}

To assess the activity of antioxidant enzymes, approximately $0.3 \mathrm{~g}$ of fresh matter were grounded in liquid nitrogen and homogenized in extraction medium comprising $0.1 \mathrm{M}$ potassium phosphate buffer, $\mathrm{pH} 6.8$, $0.1 \mathrm{mM}$ ethylenediaminetetraacetic acid (EDTA), $1 \mathrm{mM}$ phenylmethanesulfonyl fluoride (PMSF) and 1\% (w/v) polyvinylpolypyrrolidone (PVPP) (Peixoto et al. 1999). The samples were centrifuged at $12,000 \mathrm{xg}$ for $15 \mathrm{~min}$ at $4^{\circ} \mathrm{C}$ and the supernatant was used for superoxide dismutase (SOD, EC 1.15.1.1), catalase (CAT, EC 1.11.1.6), peroxidase (POX, E.C. 1.11.1.7), ascorbate peroxidase (APX, EC 1.11.1.11) and glutathione reductase (GR, EC 1.8.1.7) analyses.

SOD activity was determined by the addition of $50 \mu \mathrm{L}$ of enzymatic extract to $5 \mathrm{~mL}$ of reaction solution containing $50 \mathrm{mM}$ potassium phosphate buffer, $\mathrm{pH} 7.8,13 \mathrm{mM}$ methionine, $0.1 \mathrm{mM}$ EDTA, $75 \mathrm{mM}$ nitrobluetetrazolium (NBT) and $2 \mathrm{mM}$ riboflavin. The reaction was conducted at $25{ }^{\circ} \mathrm{C}$ in a reaction chamber under a $15 \mathrm{~W}$ fluorescent lamp for $5 \mathrm{~min}$. The amount of blue formazan produced by NBT photoreduction was measured by absorbance at 560 $\mathrm{nm}$. A reaction solution identical to the solution described above but kept in the dark for the same amount of time was prepared, and the absorbance at $560 \mathrm{~nm}$ of this solution was subtracted from the absorbance of the sample that was illuminated (Giannopolitis \& Ries 1977). One unit of SOD was defined as the quantity of enzyme required to inhibit NBT photoreduction by $50 \%$ (Beauchamp \& Fridovich 1971).

CAT activity was determined by the addition of 0.1 $\mathrm{mL}$ of enzymatic extract to $2.9 \mathrm{~mL}$ of reaction solution consisting of $50 \mathrm{mM}$ potassium phosphate buffer, $\mathrm{pH} 7.0$ and $12.5 \mathrm{mM} \mathrm{H}_{2} \mathrm{O}_{2}$ (Havir \& McHale 1987). The decrease in the absorbance during the first minute of the reaction was measured at $240 \mathrm{~nm}$ at $25^{\circ} \mathrm{C}$. The enzymatic activity 
Phytoremediation of arsenic-contaminated water: the role of antioxidant metabolism of Azolla caroliniana Willd. [Salviniales]

was calculated using a molar extinction coefficient of 36 $\mathrm{M}^{-1} \mathrm{~cm}^{-1}$ (Anderson et al. 1995) and expressed as $\mu$ moles of $\mathrm{H}_{2} \mathrm{O}_{2} \mathrm{~min}^{-1} \mathrm{mg}^{-1} \mathrm{FW}$.

POX activity was determined by the addition of $0.1 \mathrm{~mL}$ of enzymatic extract to $4.9 \mathrm{~mL}$ of reaction medium consisting of $25 \mathrm{mM}$ potassium phosphate buffer, pH 6.8, $20 \mathrm{mM}$ pyrogallol and $20 \mathrm{mM} \mathrm{H}_{2} \mathrm{O}_{2}$. Purpurogallin production was determined by the increase in absorbance at $420 \mathrm{~nm}$ during the first minute of the reaction at $25^{\circ} \mathrm{C}$. The enzymatic activity was calculated using a molar extinction coefficient of $2.47 \mathrm{M}^{-1} \mathrm{~cm}^{-1}$ (Chance \& Maehley 1955) and expressed as $\mu$ moles of $\mathrm{H}_{2} \mathrm{O}_{2} \mathrm{~min}^{-1} \mathrm{mg}^{-1} \mathrm{FW}$ (fresh weight).

APX activity was determined by the addition of $0.1 \mathrm{~mL}$ of enzymatic extract to $2.9 \mathrm{~mL}$ of a reaction medium consisting of $50 \mathrm{mM}$ potassium phosphate buffer, $\mathrm{pH} 6.0,0.8 \mathrm{mM}$ ascorbic acid and $1 \mathrm{mM} \mathrm{H}_{2} \mathrm{O}_{2}$ (Nakano \& Asada 1981). The decrease in the absorbance at $209 \mathrm{~nm}$ was measured during the first minute of the reaction at $25^{\circ} \mathrm{C}$. The enzymatic activity was calculated using a molar extinction coefficient of $2.8 \mathrm{M}^{-1} \mathrm{~cm}^{-1}$ (Anderson et al. 1995) and expressed as $\mu$ moles ascorbic acid $\mathrm{min}^{-1} \mathrm{mg}^{-1} \mathrm{FW}$.

GR activity was determined by the addition of $0.1 \mathrm{~mL}$ of enzymatic extract to $0.9 \mathrm{~mL}$ of reaction solution containing $0.1 \mathrm{M}$ tris- $\mathrm{HCl}$ buffer, $\mathrm{pH}$ 7.5, $1 \mathrm{mM}$ GSSG and $0.1 \mathrm{mM}$ NADPH (Carlberg \& Mannervik 1985). The decrease in the absorbance at $340 \mathrm{~nm}$ was measured during the first minute of the reaction at $30{ }^{\circ} \mathrm{C}$. The enzymatic activity was calculated using a molar extinction coefficient of 6.22 $\mathrm{M}^{-1} \mathrm{~cm}^{-1}$ (Anderson et al. 1995) and expressed as $\mu$ moles glutathione $\mathrm{min}^{-1} \mathrm{mg}^{-1} \mathrm{FW}$.

\section{Effects of arsenic on non-enzymatic antioxidants}

\section{Determination of thiols component content}

Samples of plants $(0.5 \mathrm{~g})$ were macerated in liquid nitrogen and then added to $6 \mathrm{~mL}$ of reaction solution containing $0.1 \mathrm{M}$ Tris-HCl buffer ( $\mathrm{pH}$ 8.0), $1 \mathrm{mM}$ EDTA and $1 \%$ ascorbic acid. The homogenized extract was centrifuged at $10,000 \mathrm{xg}$ for $10 \mathrm{~min}$ at $4{ }^{\circ} \mathrm{C}$ (Meuwly \& Rauser 1992), and the supernatant was used for the determination of the total soluble and non-protein thiols content.

The total thiols content was determined in $0.5 \mathrm{~mL}$ of supernatant added to $1.5 \mathrm{~mL}$ of potassium phosphate buffer (0.2 $\mathrm{mol} \mathrm{L}^{-1}, \mathrm{pH}$ 8.2), $0.1 \mathrm{~mL}$ Ellman's reagent [5,5' - dithiobis-(2-nitrobenzoic acid)] $\left(0.01 \mathrm{~mol} \mathrm{~L}^{-1}\right)$ and 7.9 $\mathrm{mL}$ of methanol. After $15 \mathrm{~min}$ of reaction at $37^{\circ} \mathrm{C}$, the absorbance at $412 \mathrm{~nm}$ was determined. Using a molar extinction coefficient of $13,100 \mathrm{M}^{-1} \mathrm{~cm}^{-1}$, the total thiols content was calculated, and the results are expressed as nmoles of SH g-1 FW (Sedlak \& Lindsay 1968).

The non-protein thiols content was determined in $5.0 \mathrm{~mL}$ aliquots of supernatant added to $1.0 \mathrm{~mL}$ of trichloroacetic acid $50 \%(\mathrm{w} / \mathrm{v})$ and $4.0 \mathrm{~mL} \mathrm{H}_{2} \mathrm{O}$ and maintained for $1 \mathrm{~h}$ on ice. The samples were centrifuged at 10,000 xg for $15 \mathrm{~min}$, and $2.0 \mathrm{~mL}$ aliquots were added to $4.0 \mathrm{~mL}$ of potassium phosphate buffer $\left(0.4 \mathrm{~mol} \mathrm{~L}^{-1}, \mathrm{pH} 8.9\right)$ and $0.1 \mathrm{~mL}$ of Ellman's reagent $\left(0.01 \mathrm{~mol} \mathrm{~L}^{-1}\right)$. After $5 \mathrm{~min}$ at room temperature, the absorbance at $412 \mathrm{~nm}$ was determined. Using a molar extinction coefficient of $13,100 \mathrm{~mol}^{-1} \mathrm{~L} \mathrm{~cm}^{-1}$, the non-protein thiols content was calculated, and the results are expressed as nmoles of $\mathrm{SH} \mathrm{g}^{-1} \mathrm{FW}$ (Sedlak \& Lindsay 1968).

\section{Determination of anthocyanins content}

Anthocyanins were extracted using $1 \%$ ethanol acidified with $\mathrm{HCl}$ (Kamperidou \& Vasilakakis 2006). The samples were refrigerated for $14 \mathrm{~h}$ and filtered, and the absorbance of the extracts was measured at $512 \mathrm{~nm}$. Anthocyanin content was estimated as pelargonidin 3-glucoside at 510 $\mathrm{nm}$, using a molar absorptivity coefficient of 36.000 and expressed as milligrams per $100 \mathrm{~g}$ of FW.

\section{Experimental design and statistical analysis}

The experiments followed a completely randomized experimental design with six replicates. Data were analyzed by ANOVA and linear regression. The equations were calculated using the software SAS 9.1 (SAS Institute Inc. 2004).

\section{Results}

\section{Arsenic uptake and effect on growth and tolerance index of $\boldsymbol{A}$. caroliniana}

Arsenic uptake by $A$. caroliniana increased with increasing concentrations of the metalloid in the solution, reaching $386.1 \mu^{\mathrm{g} \mathrm{g}^{-1} \mathrm{DW}}$ (dry weight) at the highest dose (Tab. 1). The saturation of the absorption and accumulation mechanisms for this element had not occurred.

The growth of A. caroliniana was affected by As in the nutrient solution, occurring a decrease in the RGR with the increment of the concentration of the pollutant. Similarly, tolerance index also decreased in response to increasing concentrations of As (Tab. 1).

\section{Effect of arsenic on enzymatic activity}

The activity of the antioxidant enzymes indicated that As accumulation induces a strong antioxidant response in A. caroliniana (Fig. 1 A-E). The SOD activity was greatly increased at As concentration of $1 \mathrm{mg} \mathrm{L}^{-1}$. At the highest concentration of the metalloid, however, the activity of the enzyme decreased but still remained higher than in the control (Fig. 1A). 
Table 1. As uptake, relative growth rate and tolerance index in Azolla caroliniana exposed to As during five days.

\begin{tabular}{|c|c|c|c|}
\hline $\begin{array}{l}\text { As concentration } \\
{\left[\mathrm{mg} \mathrm{L}^{-1}\right]}\end{array}$ & $\begin{array}{l}\text { As uptake } \\
{\left[\mu g g^{-1} D W\right]}\end{array}$ & $\begin{array}{l}\text { Relative growth rate } \\
{\left[\mathrm{mg} \mathrm{g}^{-1} \mathbf{F W} \text { day }^{-1}\right]}\end{array}$ & $\begin{array}{c}\text { Tolerance index } \\
\text { [\%] }\end{array}$ \\
\hline 0.0 & 25.4 e & 109.97 a & $100 \mathrm{a}$ \\
\hline 0.25 & $209.1 \mathrm{~d}$ & $76.98 \mathrm{~b}$ & $70 \mathrm{~b}$ \\
\hline 0.5 & 271.2 c & $72.03 \mathrm{~b}$ & $65.5 c$ \\
\hline 1.0 & $323.5 \mathrm{~b}$ & $62.69 c$ & $57 \mathrm{~d}$ \\
\hline 1.5 & $386.1 \mathrm{a}$ & $56.94 c$ & $51.78 \mathrm{~d}$ \\
\hline
\end{tabular}

Means followed by the same letter were not significantly different according to Tukey's test at $5 \%$ probability.

CAT activity increased in A. caroliniana by $26.44 \%$ at $0.25 \mathrm{mg} \mathrm{L}^{-1}$ As. At higher concentrations, however, the enzyme activity was negatively affected by exposure to the pollutant (Fig. 1B).

POX activity was extremely low in the control plants and increased after the exposure of $A$. caroliniana to the pollutant. Indeed, POX activity was increased by $39.72 \%$ in A. caroliniana at $1.0 \mathrm{mg} \mathrm{L}^{-1}$ As. Enzymatic activity decreased in plants exposed to the highest As concentration, although POX activity still has remained higher than in the control (Fig. 1 C). A very similar pattern was observed in relation to GR enzyme whose activity increased at $1.0 \mathrm{mg} \mathrm{L}^{-1} \mathrm{As}$ and decreased in the subsequent concentration (Fig. $1 \mathrm{E}$ ).

APX was the most sensitive enzyme to As toxicity (Fig. 1D). Actually, the activity of this enzyme showed a sharp decrease in plants exposed to concentrations above 0.25 $\mathrm{mg} \mathrm{L}^{-1} \mathrm{As}$, indicating that even low pollutant concentrations are able to inactivate the enzyme.

\section{Effect of arsenic on non-enzymatic antioxidants}

The content of non-enzymatic antioxidants total thiols, non-protein thiols (Fig. 2A, B) and anthocyanins (Fig. 3) had increases in all the As concentrations. Unlike what occurred with the enzymes the concentration of non-enzymatic antioxidants did not decrease in the highest concentration of the pollutant, indicating lower sensitivity of these molecules to damage triggered by the metalloid.

\section{Discussion}

This study evaluated the effect of As exposure on growth, As accumulation and antioxidant defences of Azolla caroliniana. Among all the species of Azolla, A. caroliniana proved to be able to accumulate the highest As concentration (Mahmud et al. 2008; Sánchez-Viveros et al. 2011; Li et al. 2016), which makes this plant an interesting tool for use in phytoremediation. However, the accumulation of As triggered several types of cell damage (Islam et al. 2015), which can be observed through increasing concentrations of oxidative stress biomarkers, such as enzymes and thiols, and by the decrease in plant growth (Dazy et al. 2012).
Decrease in the growth rate is a typical plant response to As exposure (Farooq et al. 2016). Nevertheless, although As exposure reduced the RGR, $A$. caroliniana continued to show growth even after accumulating high concentrations of the pollutant. Usually, the reduction in the growth of plants subjected to As is much more drastic than what was observed in A. caroliniana (Farnese et al. 2014). The maintenance of growth is an important parameter to assess the tolerance of plants to toxic chemical pollutants and is an essential feature in plants used in phytoremediation programs (Chen et al. 2016).

The ability of $A$. caroliniana to maintain the growth is probably a result of the activation of defence mechanisms involved in the mitigation of damage triggered by As (Kandziora-Ciupa et al. 2016). Toxic compounds promote an increase in ROS generation, which results in oxidative damage to biomolecules and subcellular structures (Erinle et al. 2016). To prevent these harmful effects, plants develop tolerance mechanisms, such as the activation of enzymatic and non-enzymatic antioxidant systems, which are also indicators of oxidative stress in plants (Brain \& Cedergreen 2009; Gusman et al. 2013).

Antioxidant enzymes have an important role in the defence against As toxicity and are considered non-specific biomarkers of oxidative stress (Dazy et al. 2012). The first enzyme involved in the detoxification process is SOD, which promotes the conversion of superoxide radicals $\left(\mathrm{O}_{2}^{-}\right)$to hydroxide peroxide $\left(\mathrm{H}_{2} \mathrm{O}_{2}\right)$. Therefore, $\mathrm{SOD}$ activity results in increased $\mathrm{H}_{2} \mathrm{O}_{2}$ generation and must be accompanied by an increase in the activity of enzymes responsible for scavenging $\mathrm{H}_{2} \mathrm{O}_{2}$, such as CAT and POX. The increase of SOD activity in response to As toxicity observed in this study has also been reported in other plants, such as Lactuca sativa (Gusman et al. 2013) and Eichhornia crassipes (Andrade et al. 2016). However, when As levels are very high, the extent of the damage caused by the pollutant decreases enzyme activity. The decrease in SOD activity at high heavy metal concentrations may be attributed to the inactivation of the enzyme by $\mathrm{H}_{2} \mathrm{O}_{2}$ or to the existence of other ROS and the inactivation of other enzymes involved in the degradation of these compounds (Khan et al. 2009).

The enzymes CAT and POX act directly to scavenge $\mathrm{H}_{2} \mathrm{O}_{2}$ (Sharma et al. 2012), whereas APX and GR participate in the ascorbato-glutathione cycle that also promotes $\mathrm{H}_{2} \mathrm{O}_{2}$ 
Phytoremediation of arsenic-contaminated water: the role of antioxidant metabolism of Azolla caroliniana Willd. [Salviniales]
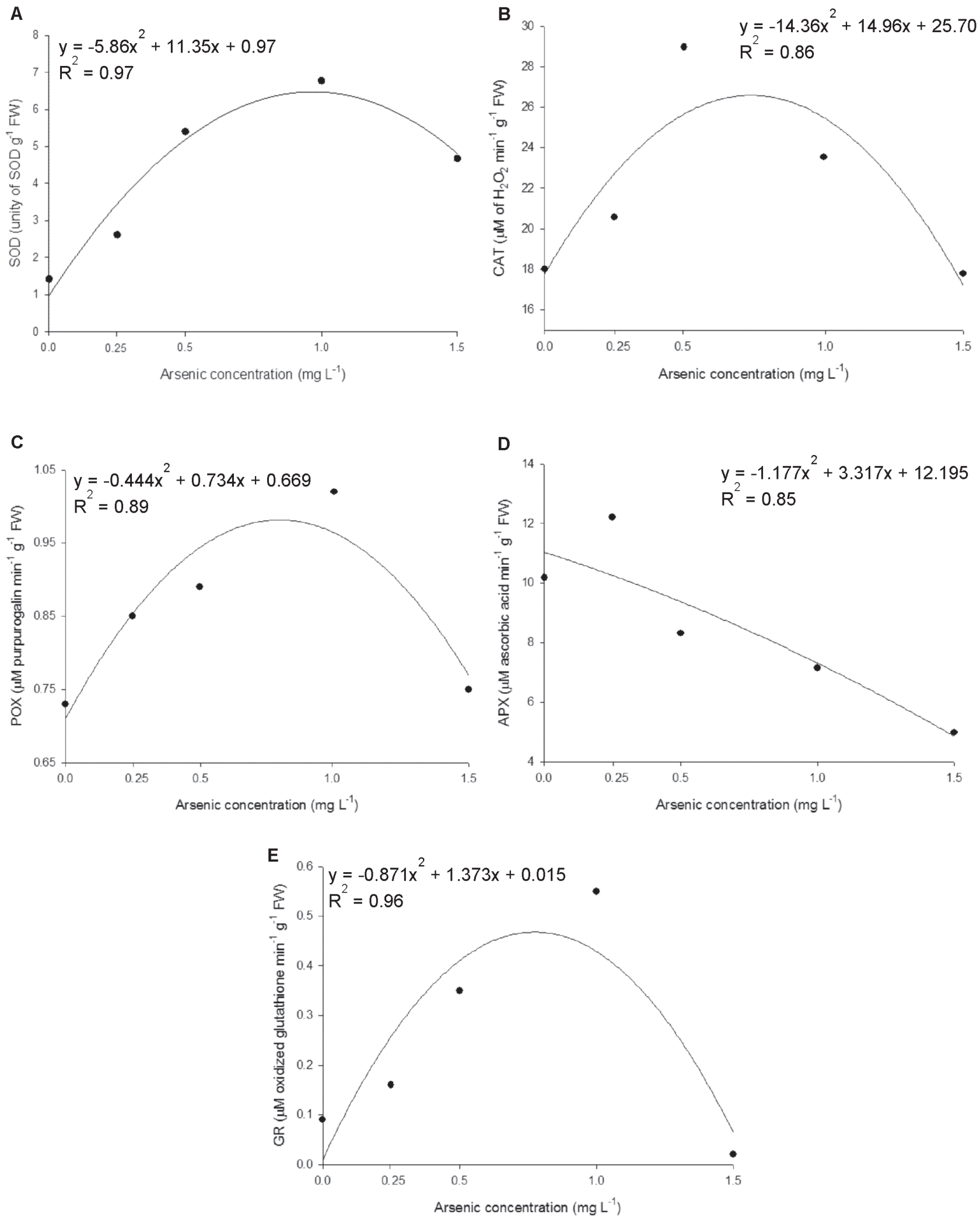

Figure 1. Activity of antioxidant enzymes in Azolla caroliniana exposed to arsenic during five days. The parameters included Superoxide dismutase activity (SOD) (A); catalase activity (CAT) (B); peroxidase activity (POX) (C); ascorbate peroxidase activity (APX) (D); and glutathione reductase (GR) (E). 
A

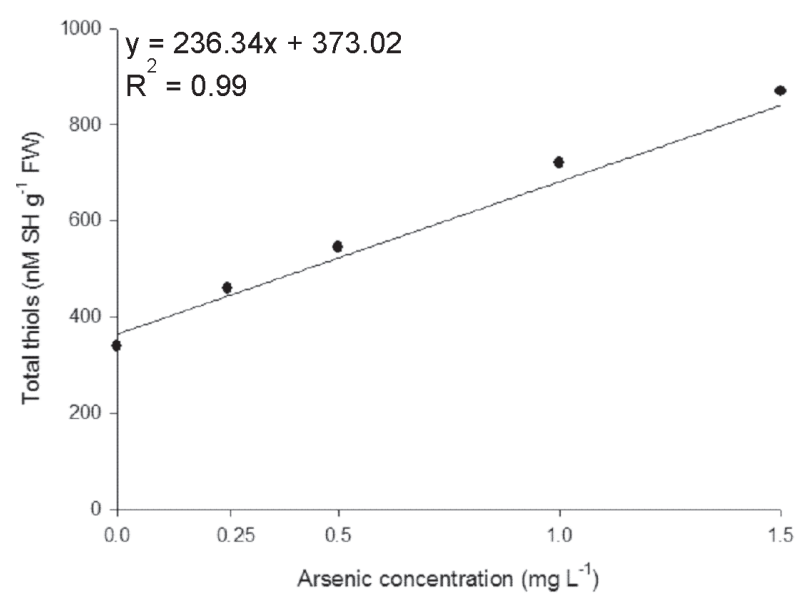

B

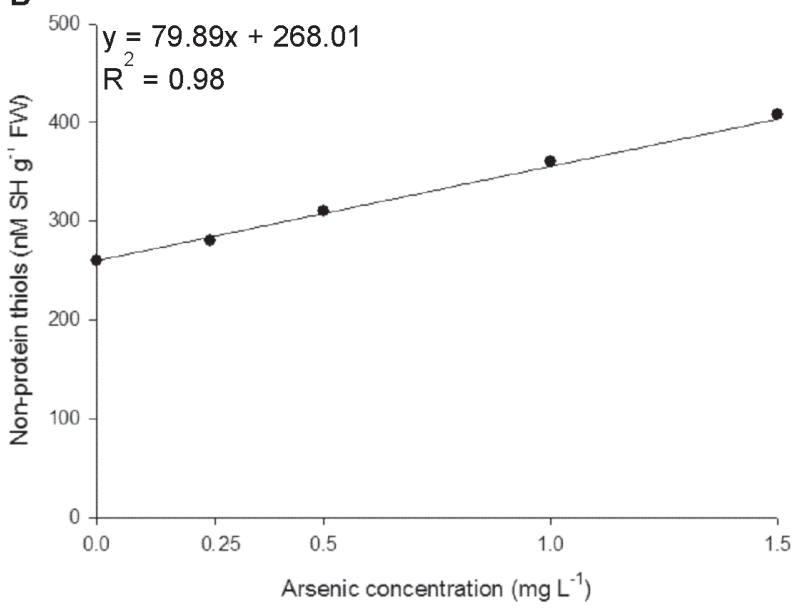

Figure 2. Content of non-enzymatic antioxidants in Azolla caroliniana exposed to arsenic during five days. The parameters included total thiols (A) and non-protein thiols (B).

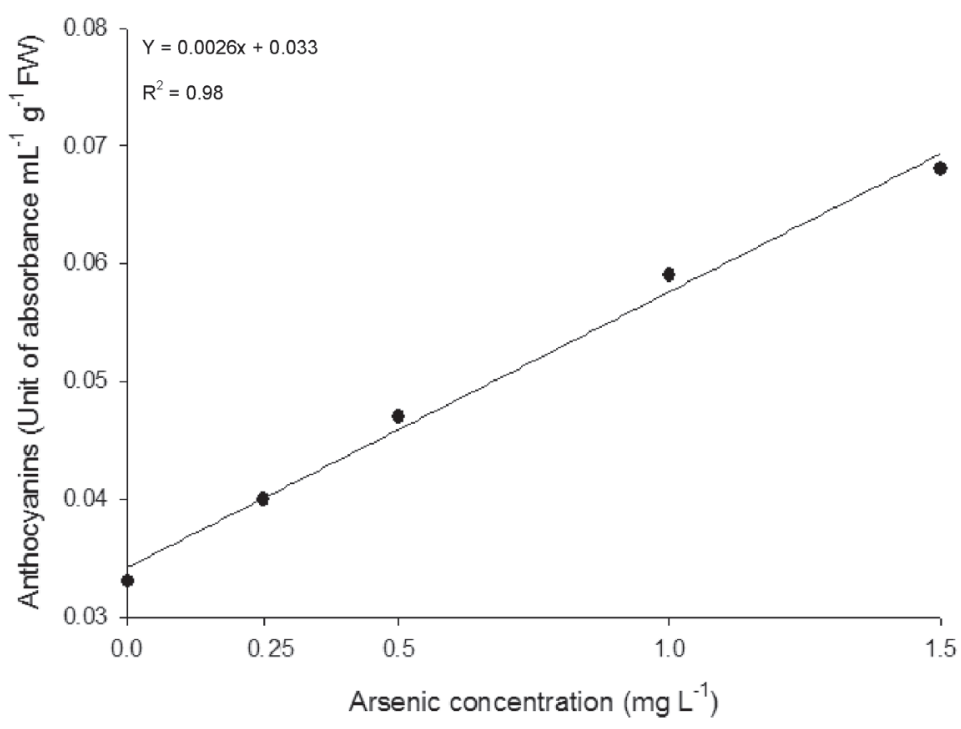

Figure 3. Content of anthocyanins in Azolla caroliniana exposed to arsenic during five days.

decomposition (Caverzan et al. 2012). Accordingly, these enzymes were important in A. caroliniana for defence against ROS at low As concentrations, but in higher concentrations the toxic effects of the pollutant inactivated the enzymes. Similar results were observed in rice (Shri et al. 2009) and aquatic plants (Farnese et al. 2014; Andrade et al. 2016) after exposure to high As concentrations. Given that plant growth was maintained even in the highest concentrations of the metalloid, it is likely that $A$. caroliniana uses other strategies for survival. In fact, the non-enzymatic antioxidant content (anthocyanins, total thiols and non-protein thiols) was increased in A. caroliniana plants exposed to all As concentrations.

Anthocyanins are a large class of water-soluble pigments in the flavonoid group that are found in all plant tissues. Environmental stresses are well known to stimulate production of anthocyanin, and studies have shown that anthocyanins can quench almost all types of ROS, including $\mathrm{O}_{2}^{-*}$ and $\mathrm{H}_{2} \mathrm{O}_{2}$ (Liu et al. 2016). Moreover, anthocyanins have roughly four times greater antioxidant capacity than $\alpha$-tocopherol and ascorbate (Agati \& Tattini 2010). The antioxidative properties of anthocyanins arise from their high reactivity as hydrogen or electron donors, their ability to chelate transition metal ions and the ability of the polyphenol-derived radicals to stabilize and delocalize unpaired electrons (Duan et al. 2007). The increase in anthocyanin content might also be related to phosphate deficiency. Phosphate and arsenate are analogues and compete for the same sorption sites in the root apoplast and for the same uptake system in the root plasmalemma. As a consequence, As in the nutrient solution decreases 
phosphate uptake, and anthocyanin synthesis is considered as a visible marker of As stress (Catarecha et al. 2007; Shaibur et al. 2013).

In addition to anthocyanins, thiol levels also increased in plants exposed to the pollutant. In this study, As was supplied as arsenate because this is the major form found in oxygenated environments such as surface water. In plant cells, arsenate is readily reduced to arsenite, the first step in the main As detoxification pathway (Finnegan \& Chen 2012; Singh et al. 2015). Non-protein thiols contain chains of $\gamma$-glutamilcystein rich in sulphydryl groups that promote the chelation of arsenite and subsequent compartmentalization in the vacuole (Leão et al. 2014a; Dixit et al. 2015). Complexed forms of As had lower toxicity than free forms (Zagorchev et al. 2013), which was reflected in maintaining the growth capacity of $A$. caroliniana.

The data obtained in this article allow us to conclude that the activation of antioxidant system is a crucial aspect that ensures the maintenance of growth and survival of $A$. caroliniana plants in toxic As concentrations. Unlike the observed for several other plants, however, in A. caroliniana the activity of antioxidant enzymes appears to be effective only at low concentrations of the pollutant. Therefore, the increased synthesis of non-enzymatic antioxidants is most likely the main factor responsible for the As tolerance of $A$. caroliniana. The high tolerance of the plant to As, associated with its high capacity for pollutant accumulation, makes A. caroliniana an interesting tool for the decontamination of aquatic environments. The present results also have important implications for agriculture, since they can be used as a basis for treatment of irrigation water in regions contaminated with As.

\section{Acknowledgements}

The authors thank CNPq and CAPES for fellowships and FAPEMIG for financial support.

\section{References}

Agati G, Tattini M. 2010. Multiple functional roles of flavonoids in photoprotection. New Phytologist 186: 786-793.

Anderson MD, Prasad TK, Stewart CR. 1995. Changes in isozyme profiles of catalase, peroxidase, and glutathione reductase during acclimation to chilling in mesocotylus of maize seedlings. Plant Physiology 109: 1247-1257.

Andrade HM, Oliveira JA, Farnese FS, et al. 2016. Arsenic toxicity: cell signalling and the attenuating effect of nitric oxide in Eichhornia crassipes. Biologia Plantarum 60: 173-180.

Beauchamp C, Fridovich I. 1971. Superoxide dismutase: improved assays and an assay applicable to acrylamide gels. Analytical Biochemistry 44: 276-287.

Benniceli R, Stepniewska Z, Banach A, Szajnocha K, Ostrowski J. 2004. The ability of Azolla caroliniana to remove heavy metals ( $\mathrm{Hg}(\mathrm{II}), \mathrm{Cr}$ (III), $\mathrm{Cr}$ (VI) from municipal waste water. Chemosphere 55: 141-146.

Brain RA, Cedergreen N. 2009. Biomarkers in aquatic plants: selection and utility. Reviews of Environmental Contamination and Toxicology 198: 49-109.
Carlberg C, Mannervik B. 1985. Glutathione reductase. In: Colowick N, Kaplan N. (eds.) Methods in enzymology. New York, Academic Press. p. 488-495.

Catarecha P, Segura MD, Franco-Zorrilla JM, et al. 2007. A mutant of the Arabidopsis phosphate transporter PHT1;1 displays enhanced arsenic accumulation. Plant Cell 19: 1123-1133.

Caverzan A, Passaia G, Rosa SB, Ribeiro CW, Lazzarotto F, Margis-Pinheiro M. 2012. Plant responses to stresses: role of ascorbate peroxidase in the antioxidant protection. Genetics and Molecular Biology 35: 1011-1019.

Chance B, Maehley AC. 1955. Assay of catalases and peroxidases. In: Abelson J, Simon M. (eds.) Methods in enzymology. New York, Academic Press. p. 764-775.

Chen J, Xu H, Sun Y, et al. 2016. Interspecific differences in growth response and tolerance to the antibiotic sulfadiazine in ten clonal wetland plants in South China. Science of Total Environment 543: 197-205.

Clark RB. 1975. Characterization of phosphatase of intact maize roots. Journal of Agricultural Food Chemistry 23: 458-460.

Dazy M, Masfaraud J, Férard J. 2012. Induction of oxidative stress biomarkers associated with heavy metal stress in Fontinalis antipyretica Hedw. Chemosphere 75: 297-302.

Dixit G, Singh AP, Kumar A, et al. 2015. Sulfur mediated reduction of arsenic toxicity involves efficient thiol metabolism and the antioxidant defense system in rice. Journal of Hazardous Materials 298: 241-251.

Duan X, Jiang Y, Su X, Zhang Z, Shi J. 2007. Antioxidant properties of anthocyanins extracted from litchi (Litchi chinenesis Sonn.) fruit pericarp tissues in relation to their role in the pericarp browning. Food Chemistry 101: 1365-1371.

Erinle KO, Jiang Z, Li M, et al. 2016. Oxidative stress response induced in an atrazine phytoremediating plant: Physiological responses of Pennisetum glaucum to high atrazine concentrations. International Journal of Phytoremediation 18: 1187-1194.

Farnese FS, Oliveira JA, Lima FS, Leão GA, Gusman GS, Silva LC. 2014. Evaluation of the potential of Pistia stratiotes L. (water lettuce) for bioindication and phytoremediation of aquatic environments contaminated with arsenic. Brazilian Journal of Biology 74: S103-S112.

Farooq MA, Islam F, Ali B, et al. 2016. Arsenic toxicity in plants: cellular and molecular mechanisms of its transport and metabolism. Environmental and Experimental Botany 132: 42-52.

Fayiga AO, Saha UK. 2016. Arsenic hyperaccumulating fern: Implications for remediation of arsenic contaminated soils. Geoderma 284: 132-143.

Finnegan PM, Chen W. 2012. Arsenic toxicity: the effects on plant metabolism. Frontiers in Physiology 3: 182.

Giannopolitis CN, Ries SK. 1977. Superoxide dismutases.: I. Occurrence in higher plants. Plant Physiology 59: 309-314.

Gusman GS, Oliveira JA, Farnese FS, Cambraia J. 2013. Mineral nutrition and enzymatic adaptation induced by arsenate and arsenite exposure in lettuce plants. Plant Physiology and Biochemistry 71: 307-314.

Havir EA, McHale NA. 1987. Biochemical and developmental characterization of multiple forms of catalase in tobacco leaves. Plant Physiology 84: 450-455.

Hunt R. 1978. Plant growth analysis. London, Edward Arnold Limited.

Islam E, Khan MT, Irem S. 2015. Biochemical mechanisms of signaling: Perspectives in plants under arsenic stress. Ecotoxicology and Environmental Safety 114: 126-133.

Kamperidou I, Vasilakakis M. 2006. Effect of propagation material on some quality attributes of strawberry fruit (Fragarria $x$ ananassa var. Selva). Scientia Horticulturae 107: 137-142.

Kandziora-Ciupa M, Ciepał R, Nadgórska-Socha A, Barczyk G. 2016. Accumulation of heavy metals and antioxidant responses in Pinus sylvestris L. needles in polluted and non-polluted sites. Ecotoxicology 25: 970-981.

Karn SK. 2015. Arsenic (As) contamination: a major risk factor in Xinjiang Uyghur autonomous region of China. Environnmental Pollution 207: 434-435.

Khan I, Ahmad A, Iqbal M. 2009. Modulation of antioxidant defense system for arsenic detoxification in Indian mustard. Ecotoxicology and Environmental Safety 72: 626-634. 
Leão GA, Oliveira JA, Farnese FS, Gusman GS, Felipe RTA. 2014a. Sulfur metabolism: different tolerances of two aquatic macrophytes exposed to arsenic. Ecotoxicology and Environmental Safety 105: 36-42.

Leão GA, Oliveira JA, Felipe RTA, Farnese FS, Gusman GS. 2014b. Anthocyanins, thiols, and antioxidant scavenging enzymes are involved in Lemna gibba tolerance to arsenic. Journal of Plant Interactions 9: 143-151.

Li N, Wang J, Song W. 2016. Arsenic uptake and translocation in plants. Plant and Cell Physiology 57: 4-13.

Liu S, Xu Q, Li X, et al. 2016. Effects of high hydrostatic pressure on physicochemical properties, enzymes activity, and antioxidant capacities of anthocyanins extracts of wild Lonicera caerulea berry. Innovative Food Science and Emerging Technologies 36: 48-58.

Mahmud R, Inoue N, Kasajima S, Shaheen R. 2008. Assessment of potential indigenous plant species for the phytoremediation of arsenic-contaminated areas of Bangladesh. International Journal of Phytoremediation 10: 119-132.

Marin AR, Pezeshki SR, Masschenlyn PH, Choi HS. 1993. Effect of dimethylarsenic acid (DMAA) on growth tissue arsenic and photosynthesis in rice plants. Journal of Plant Nutrition 16: 865-880.

Meuwly P, Rauser WE. 1992. Alteration of thiol pool in roots and shoots of maize seedlings exposed to cadmium. Plant Physiology 99: 8-15.

Nakano Y, Asada K. 1981. Hydrogen peroxide is scavenged by ascorbatespecific peroxidase in spinach chloroplasts. Plant Cell Physiology 22: 867-880.

Palácio SM, Espinoza-Quiñones FR, Pauli AR, et al. 2016. Water quality of Marreco River, Brazil, based on principal component analysis and toxicological assays. Water, Air, \& Soil Pollution 227: 307.

Peixoto PHP, Cambraia J, Sant'ana R, Mosquim PR, Moreira MA. 1999. Aluminum effects on lipid peroxidation and on activities of enzymes of oxidative metabolism in sorghum. Revista Brasileira de Fisiololgia Vegetal 11: 137-143

Podder MS, Majumder CB. 2016. Sequestering of As(III) and As(V) from wastewater using a novel neem leaves/MnFe2O4 composite biosorbent. International Journal of Phytoremediation 18: 1237-1257.

SAS Institute Inc. 2004. SAS/STAT 9.1 User's guide. Cary, NC: SAS Institute Inc. Sadee BA, Foulkes ME, Hill SJ. 2016. A study of arsenic speciation in soil, irrigation water and plant tissue: A case study of the broad bean plant, Vicia faba. Food Chemistry 210: 362-370.

Sánchez-Viveros G, Ferrera-Cerrato R, Alarcón A. 2011. Short-term effects of arsenate-induced toxicity on growth, chlorophyll and carotenoid contentes, and total contente of phenolic compounds of Azolla filiculoides. Water, Air, \& Soil Pollution 217: 455.

Sedlak J, Lindsay RH. 1968. Estimation of total, protein bound, and nonprotein sulphydryl groups in tissue by Ellmans's reagent. Analytical Biochemistry 25: 192-208.

Shaibur MR, Adjadeh TA, Kawai S. 2013. Effect of phosphorus on the concentrations of arsenic, iron and some other elements in barley grown hydroponically. Journal of Soil Science and Plant Nutrition 13: 87-98.

Sharma P, Jha AB, Dubey RS, Pessarakli M. 2012. Reactive oxygen species, oxidative damage, and antioxidative defense mechanism in plants under stressful conditions, Journal of Botany 2012: 1-26

Shri M, Kumar S, Chakrabarty D, et al. 2009. Effect of arsenic on growth, oxidative stress, and antioxidant system in rice seedlings, Ecotoxicology and Environmental Safety 72: 1102-1110.

Silveira NM, Oliveira JA, Ribeiro C, Canatto RA, Siman L, Farnese F. 2015. Nitric oxide attenuates oxidative stress induced by arsenic in lettuce (Lactuca sativa) leaves. Water, Air, \& Soil Pollution 226: 379.

Singh AP, Dixit G, Kumar A, et al. 2015. Nitric oxide alleviated arsenic toxicity by modulation of antioxidants and thiol metabolism in rice (Oryza sativa L.). Frontiers in plant Science 6: 1272.

Srivastava S, Akkarakaran JJ, Sounderajan S, Shrivastava M, Suprasanna P. 2016. Arsenic toxicity in rice (Oryza sativa L.) is influenced by sulfur supply: impact on the expression of transporters and thiol metabolism. Geoderma 270: 33-42.

Wilkins DA. 1978. The measurement of tolerance to edaphic factors by means of root growth. New Phytologist 80: 623-633.

Zagorchev L, Seal CE, Kranner I, Odjakova M. 2013. A central role for thiols in plant tolerance to abiotic stress. International Journal of Molecular Sciences 14: 7405-7432.

Zhang X, Lin AJ, Zhao F, Xu G, Duan G, Zhu Y. 2008. Arsenic accumulation by the aquatic fern Azolla: Comparison of arsenate uptake, speciation and efflux by A. caroliniana and A. filiculoides. Environmental Pollution 156: 1149-1155. 